\title{
Advances in Bacterial Specific Imaging
}

\author{
David Wareham $^{1,2}$, J. Michael ${ }^{1}$ and Satya $\operatorname{Das}^{1,2^{*}}$ \\ ${ }^{1}$ Department of Medical Microbiology; St Bartholomew's Hospital; West Smithfield; EC1A 7BE; London - UK. \\ ${ }^{2}$ Centre for Infectious Disease; Institute of Cell and Molecular Science; Barts and The London; Queen Mary's \\ School of Medicine and Dentistry; University of London; E1 1BB; London - UK
}

\begin{abstract}
Nuclear medicine is a powerful diagnostic technique able to detect inflammatory foci in human disease. A wide range of agents have been evaluated for their ability to distinguish lesions due to microbial infection from those due to sterile inflammation. Advances continue to be made on the use of radiolabelled antibiotics which as well as being highly specific in the diagnosis of infection may be useful in monitoring the treatment and course of disease. Here we provide an update on in-vitro and clinical studies with a number of established and novel radiopharmaceuticals
\end{abstract}

Key words: Radiopharmaceuticals, Infection specific imaging, Radiolabelled anti-infectives, ${ }^{99 \mathrm{~m}}$ Tc- ciprofloxacin

\section{INTRODUCTION}

The introduction of powerful antimicrobials in the $20^{\text {th }}$ Century has done little to reduce the morbidity and mortality of infectious diseases. The emergence of new pathogens, widespread antimicrobial resistance and uncontrolled nosocomial infection has attracted major concern whilst increasing numbers of patients with heightened susceptibility due to HIV, malignancy and immunosuppressive drugs has contributed to the burden of infection in both developing and industrialised countries. Accurate diagnosis to enable appropriate treatment is therefore central to strategies employed in the ongoing struggle against microbial infection.

Conventional methods of diagnosis, relying on examination and culture of organisms from infected foci have continued to advance embracing new technologies and automation. Despite this, the methods are still time consuming, insensitive and results often obtained too late to guide clinical decision making. Advances in imaging sites of infection have likewise proceeded at a phenomenal rate. In 2002 the role of nuclear medicine techniques in the diagnosis of deep seated infection was reviewed in this Journal (Das et al, 2002). Since then further progress has been made on the use of labelled antimicrobial agents as selective markers for the diagnosis of bacterial, tuberculous and fungal infections. Here we provide an update on work in this field and review the likely impact of such agents on the management of clinical infection.

\section{Nuclear Medicine Imaging}

Nuclear medicine offers powerful noninvasive techniques for visualization of infectious and inflammatory disorders by whole body imaging of the number and site of inflammatory foci. The ideal agent for imaging infection would combine high specifiicty with minimal side effects, low marrow, gut and renal uptake and be safe and easy to prepare (Wareham, Das and Britton, 2000).

\footnotetext{
* Author for correspondence
} 
A wide variety of approaches targeting different aspects of the inflammatory response have been developed and previously reviewed
(Gnanesegaran, Croasdale and Buscome, 2004). A summary of available agents, properties, targets and sugested uses is given in table 1.

Table 1- Agents used for imaging sites of inflammation in nuclear medicine studies

\begin{tabular}{|c|c|c|}
\hline RADIOPHARMACEUTICAL & PROPERTIES & $\begin{array}{c}\text { COMMENTS } \\
\end{array}$ \\
\hline Gallium-67 citrate $\left({ }^{67} \mathrm{Ga}\right)$ & $\begin{array}{l}\text { Associates with iron binding proteins in } \\
\text { inflamed tissue and bacteria }\end{array}$ & $\begin{array}{l}\text { Rendered obsolete by }{ }^{99 \mathrm{~m}} \text { Tc-labelled } \\
\text { compounds. Occassionally used in } \\
\text { investigation of FUO or osteomyelitis }\end{array}$ \\
\hline Radiolabelled leucocytes & $\begin{array}{l}\text { Ex-vivo }{ }^{111} \text { In or }{ }^{99 \mathrm{~m}} \text { Tc-labelled white } \\
\text { cells accumulate at sites of } \\
\text { inflammation by diapedesis and } \\
\text { chemotaxis }\end{array}$ & $\begin{array}{l}\text { Highly sensitive }>95 \% \\
{ }^{111} \text { In labelled leucocytes - abdomen, } \\
\text { thorax or vascular prosthesis imaging } \\
{ }_{99 \mathrm{~m}} \mathrm{Tc} \text { labelled leucocytes - widely } \\
\text { used, preferred in renal, genitourinary } \\
\text { and gastrointestinal imaging }\end{array}$ \\
\hline Polyclonal immunoglobulin $\mathrm{G}$ & $\begin{array}{l}{ }^{111} \text { In or }{ }^{99 \mathrm{~m}} \mathrm{Tc}-\text { labelled human } \\
\text { polyclonal } \\
\text { accumulates at sites of inflammation via } \\
\text { capillary leakage }\end{array}$ & $\begin{array}{l}\text { Higher sensitivity reported versus } \\
\text { leucocyte imaging (De Kleijn et al, } \\
\text { 1997) } \\
\text { Insensitive for vascular lesions } \\
\text { Some specificity for bacteria via } \\
\text { specific IgG - bacteria interactions }\end{array}$ \\
\hline
\end{tabular}

\begin{tabular}{|c|c|c|}
\hline Monoclonal antibodies & $\begin{array}{l}{ }^{99 \mathrm{~m}} \text { Tc-labelled antibody fragments } \\
\text { targeting granulocyte surface antigens, } \\
\text { adhesion molecules or specific bacteria }\end{array}$ & Limted human studies to date \\
\hline Cytokines & $\begin{array}{l}{ }^{111} \text { In or }{ }^{{ }^{99 m}} \text { Tc-labelled inflammatory } \\
\text { cytokines }\end{array}$ & $\begin{array}{l}\text { Inflammation specific } \\
\text { Toxic due to biological activity of } \\
\text { cytokine }\end{array}$ \\
\hline Liposomes & $\begin{array}{l}{ }^{99 \mathrm{~m}} \text { Tc-labelled } \\
\text { phospholipids } \\
\text { polymorphs }\end{array}$ & $\begin{array}{l}\text { Non-specific accumulation in liver, } \\
\text { spleen and bone marrow } \\
\text { Difficult to prepare }\end{array}$ \\
\hline Antimicrobial peptides & $\begin{array}{l}{ }^{99 \mathrm{~m}} \mathrm{Tc}-\mathrm{labelled} \text { endogenous human } \\
\text { neutrophil peptides insert into microbial } \\
\text { and some other cell membranes }\end{array}$ & $\begin{array}{l}{ }^{99} \text { Tc-labelled HNP-1 claimed to be } \\
\text { specific for experimental bacterial and } \\
\text { fungal infection in animals (Welling et } \\
\text { al, 2000) }\end{array}$ \\
\hline Antimicrobial Agents & $\begin{array}{l}{ }^{99 \mathrm{~m}} \text { Tc-labelled antibiotics, bind to } \\
\text { specific targets in living bacteria }\end{array}$ & $\begin{array}{l}\text { Should be specific for infection, may } \\
\text { enable requirement for therapy to be } \\
\text { determined. Some bacteria may be } \\
\text { resistant }\end{array}$ \\
\hline
\end{tabular}

\section{Radiolabelled Antimicrobial Agents}

The theoretical advantage of using an antimicrobial agent as the localising agent for infective foci is the selective toxicity of the compound for microbial rather than human targets. Such agents should therefore be able to distinguish between inflammation due to infection with microbial pathogens, and inflammation due to immune activity i.e. autoimmune disease where microbes are not involved. As the inability to do this is the main drawback of conventional imaging agents, radiolabelled antimicrobials have the potential to influence clinical decisions in the management of complicated conditions such as fever of unknown origin (FUO) or occult infection.

If these agents were able to predict the requirement for and the duration of antimicrobial treatment they could in turn help to not only decrease costs but also contribute to the fight against antimicrobial resistance. 


\section{Antibacterial agents}

\section{${ }^{99 \mathrm{~m}} \mathrm{Tc}$ - ciprofloxacin $\left({ }^{99 \mathrm{~m}} \mathrm{Tc}-\right.$ Infecton)}

Ciprofloxacin hydrochloride is a synthetic broadspectrum quinolone antibiotic which is taken up by Gram-positive and Gram-negative bacteria and inhibits DNA synthesis by binding to bacterial DNA gyrase. Ciprofloxacin also binds reversibly to mammalian topoisomerase II but with 1000 fold lesser affinity (Das et al, 2002). Although the drug penetrates into white cells it is not retained in the absence of bacterial infection. Following injection, only $20-30 \%$ of ciprofloxacin is bound to plasma proteins and the agent becomes widely distributed throughout the body. It is metabolised in the liver then eliminated by renal excretion during the first $24 \mathrm{hrs}$ and via the bile over the next 5 days. Ciprofloxacin associates readily with metal ions and in the preparation ${ }^{99 \mathrm{~m}} \mathrm{Tc}$ - ciprofloxacin $\left({ }^{99 \mathrm{~m}} \mathrm{Tc}-\right.$ Infecton) is complexed with ${ }^{99 \mathrm{~m}} \mathrm{Tc}$ at a concentration $(2 \mathrm{mg}) 200$ times lower than its normal therapeutic dose. ${ }^{99 \mathrm{~m}} \mathrm{Tc}-$ Infecton was introduced in 1993 and has been extensively evaluated by many groups around the world in a wide range of scenarios.

\section{In-vitro studies}

Studies in-vitro showed that Infecton was taken up and retained by living bacteria but not human leucocytes (Hall et al, 1996). Infecton was also shown to be taken up and retained by bacteria that were resistant to ciprofloxacin due to a DNA gyrase mutation but not by bacteria that were resistant due to outer membrane impermeability. In animal studies Infecton was able to distinguish sterile abscesses induced in rabbits using talc from abcesses following inoculation with Staphylococcus aureus and it has also been shown to be useful in imaging a prosthetic hip infection in a dog (Peremans et al, 2002)

\section{Clinical Studies (Fig. 1)}

A comparative study of Infecton and white cell imaging for the diagnosis of infections classified according to CDC diagnostic criteria demonstrated greater specificity for Infecton (Vinjamuri et al, 1996). This specificity (93\%) was confirmed in a follow up study enrolling 90 patients (Hall et al, 1998). The availability of Infecton in a kit form for local reconstitution and labelling, enabled a large scale multicentre evaluation to be performed in 879 patients across 8 countries (Britton et al, 2002). In this study, which included a diverse range of infections including endocarditis, tuberculosis, osteomyelitis and prosthetic joint infection, the agent had an overall sensitivity of $85.4 \%$ and specificity of $81.7 \%$ for the diagnosis of infection when classified by CDC, Duke or WHO criteria. The patients in this study underwent rigorous microbiological evaluation and in patients in whom infection could be confirmed by culture as well as clinical criteria specificities of over $90 \%$ were obtained. The agent seemed to be particularly useful in bone and joint infections including infected orthopaedic prosthesis and a number of follow up studies have been performed since.

In the study by Malamitsi et al (2003) 45 patients with suspected bone infections underwent imaging with a number of agents including ${ }^{99 \mathrm{~m}} \mathrm{Tc}$ methylene diphosphonate $\left({ }^{99 \mathrm{~m}} \mathrm{Tc}\right.$ MDP bone scanning), $\quad{ }^{99 \mathrm{~m}} \mathrm{Tc}-$ human immunoglobulin scanning, ${ }^{67}$ Ga-citrate scanning as well as ${ }^{99 m} \mathrm{Tc}$ ciprofloxacin (Infecton) imaging. With a sensitivity of $97.2 \%$ and a specificity of $80 \%$ infecton imaging was found to be useful marker of bone infection, although some false positives were seen in primary bone tumours.

Suspected prosthetic knee infection was studied and compared to leucocyte imaging by Larikka et al (2002). Thirty patients were recruited and infection was confirmed microbiologically in 8 but rejected in 22. Infecton scans were positive in all patients with microbiologically confirmed infections whereas the accuracy of white cell imaging was $90 \%$. Non specific accumulation of Infecton was observed in $59 \%$ of non-infected scans, however this disappeared by $24 \mathrm{hrs}$ highlighting the importance of extended imaging.

Osteomyelitis in sickle cell disease is difficult to distinguish from bone infarction following sickle cell crisis. Bererhi, Hussein and Wali (2003) compared the use of Infecton with 3 phase bone scanning using ${ }^{99 \mathrm{~m}} \mathrm{Tc}$ MDP in 35 patients with sickle cell disease and suspected osteomyelitis by microbiological and clinical criteria. The sensitivity and specificty of Infecton were $100 \%$ and $92 \%$ respectively compared to $88 \%$ and $64 \%$ for bone scanning.

Using a 'freeze-dried' kit formulation of ${ }^{99 \mathrm{~m}} \mathrm{Tc}$ ciprofloxacin, Obradovic et al (2003) reported a sensitivity of $94 \%$ and specificity of $82 \%$ in 27 patients with miscellaneous bone and joint infections confirmed by microbiological culture.

The use of ${ }^{99 \mathrm{~m}} \mathrm{Tc}$ - ciprofloxacin for diagnosing infection in the postoperative spine was assessed 
in studies by De Winter et al (2004) and Gemmel et al (2004). In the De Winter study 48 patients underwent 1,3 and $24 \mathrm{hr}$ imaging with $370 \mathrm{MBq}$ of ${ }^{99 \mathrm{~m}} \mathrm{Tc}$ - ciprofloxacin. The agent was found to be more specific than white cell imaging particularly when SPET imaging was performed $3 \mathrm{hrs}$ after injection in patients imaged at least 6 months after surgery. The study by Gemmel et al included only patients with microbiologically confirmed infection. Sensitivity and specificity varied with the time of imaging and use of SPET or planar acquisition. The highest specificity was reported as $92 \%$ with planar images at $24 \mathrm{hrs}$.

The freeze dried kit form of ${ }^{99 \mathrm{~m}} \mathrm{Tc}$ - ciprofloxacin (3.5mg with $555 \mathrm{MBq}^{99 \mathrm{~m}} \mathrm{Tc}$ ) has been used by Artiko et al, (2005) to localise intrabdominal infections with a sensitivity of $79 \%$ and a specificity of $92 \%$. Whilst another kit employing an insoluble redox polymer, (alpha (beta)-alanine$\mathrm{N}, \mathrm{N}$ '-diacetate has been developed by Kleisner et al, 2002 but not yet assessed in clinical practice.

The method of preparation and quality control of many of the in house preparations of ${ }^{99 \mathrm{~m}} \mathrm{Tc}$ ciprofloxacin has lead to controversy over the reliability of some of the published data (Das and Britton, 2003). A commercial preparation of ${ }^{99 \mathrm{~m}} \mathrm{Tc}$ - ciprofloxacin by DraxImage is however currently undergoing development and licencing procedures (Tossing, 2004)

\section{${ }^{99 m}$ Tc- sparfloxacin}

Sparfloxacin is a new generation 4fluoroquinolone with enhanced activity against Gram positive and mycobacteria. The drug was successfully labelled and evaluated in-vitro and in an animal model by Singh et al (2003). ${ }^{99 \mathrm{~m}} \mathrm{Tc}$ sparfloxacin bound to live but not heat killed cultures of $S$. aureus and was retained within infected abcesses in rabbits. The potential for further development of ${ }^{99 \mathrm{~m}} \mathrm{Tc}$ - sparfloxacin in clinical practice is uncertain due to concerns over phototoxicty and cardiotoxicity associated with newer quinolones (Ball, 2000).

\section{${ }^{99}$ m Tc- enroflaxacin}

Another quinolone antibiotic, enroflaxacin which has been used extensively in veterinary practice was labelled with ${ }^{99 \mathrm{~m}} \mathrm{Tc}$ and compared to ${ }^{99 \mathrm{~m}} \mathrm{Tc}$ ciproflaxacin by Sianes et al (2004).

Studies in-vitro with this preparation however did not show preferential binding to live or heat killed $S$. aureus or $C$. albicans or the ability to discriminate infectious or inflammatory abscesses in rats.

\section{${ }^{99}$ Tc- ceftizoxime}

Ceftizoxime is a 3rd generation cephalosporin antibiotic active against $S$. aureus, Streptococci and enterobacteriaciae. The drug has a wide volume of distribution and penetrates effectively into bone. The drug is not widely used in clinical practice but was effectively labelled with ${ }^{99 \mathrm{~m}} \mathrm{Tc}$ by Gomes Barreto et al (2002) and used by MartinComin et al (2004) to image bone infections.

\section{Antituberculous agents}

\section{${ }^{99 m}$ Tc- Isoniazid}

Isoniazid binds to mycolic acid in the cell walls of living mycobacteria. Isoniazid was labelled with > 95\% efficiency with ${ }^{99 \mathrm{~m}} \mathrm{Tc}$ by Singh et al [2003(a)] and found to be stable and highly protein bound in-vivo. Successful imaging of M. tuberculosis cold abscesses in rabbits was reported along with rapid washout from $S$. aureus infected abcesses suggesting the agent my be very useful for the detection and follow up of tuberculous lesions in man.

\section{Antituberculous agents}

\section{${ }^{99}$ Tc- Isoniazid}

Isoniazid binds to mycolic acid in the cell walls of living mycobacteria. Isoniazid was labelled with > 95\% efficiency with ${ }^{99 \mathrm{~m}} \mathrm{Tc}$ by Singh et al [2003(a)] and found to be stable and highly protein bound in-vivo. Successful imaging of M. tuberculosis cold abscesses in rabbits was reported along with rapid washout from $S$. aureus infected abcesses suggesting the agent my be very useful for the detection and follow up of tuberculous lesions in man.

\section{${ }^{99}$ Tre- Ethambutol}

Ethambutol inhibits transfer of mycolic acid in the cell wall of Mycobacteria. The drug was first labelled by Causse et al in 1990 for use in renal excretion studies. Verma et al (2005) used ${ }^{99 \mathrm{~m}} \mathrm{Tc}$ Ethambutol to image cold abscesses in rabbits where it had good specificity.

The agent bound only to cold abscess caused by M.tuberculosis and was readily washed out from lesions due to $S$. aureus. 


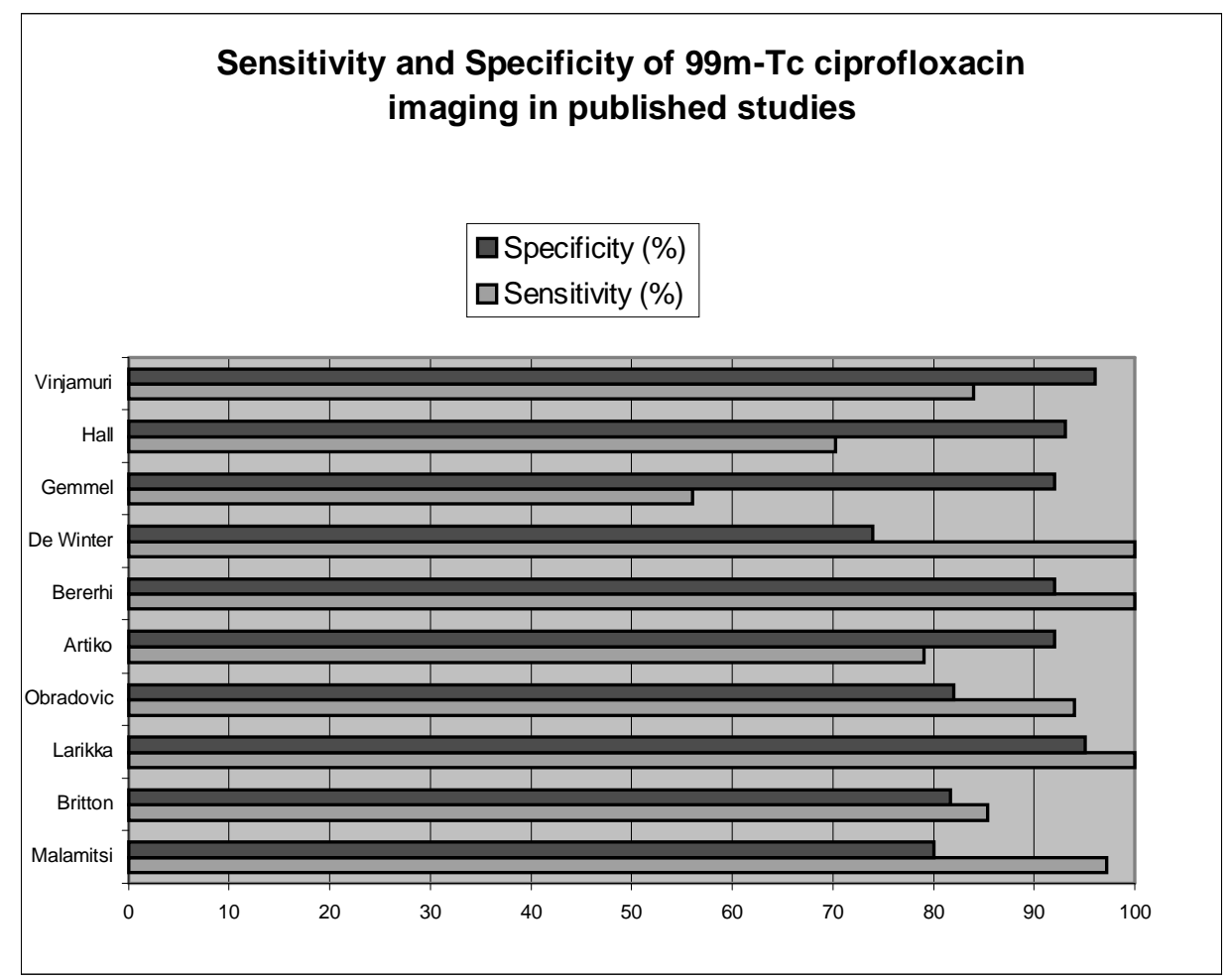

Figure 1 - Sensitivity and specificity of Infecton in published studies

They concluded that the agent was a stable, reproducible, safe and cost effective imaging method for the early diagnosis of tuberculosis.

\section{Antifungal agents}

\section{${ }^{99 m}$ Tc- Fluconazole}

Fluconazole, an azole antifungal agent, was radiolabelled with $99 \mathrm{~m}$-Tc by Lupetti et al (2002) and used for the diagnosis of Candida albicans infections in mice. Its efficacy was compared with a Tc labelled antimicrobial peptide and it was shown to be superior in differentiating between fungal and bacterial infections

\section{Voriconazole and Caspofungin}

Encouraging preliminary results have been obtained in vitro in radiolabelling of the broad spectrum antifungal agents caspofungin and voriconazole. HPLC analysis (Fig. 2) demonstrated efficient radiolabelling of caspofungin with I-125 (iodine-125) and voriconazole with Tc-99m with minimum contamination. The binding of I-125 Caspofungin to Candida albicans was over three times greater than to E.coli or Staphylococcus epidermidis. Similarly promising results were obtained from radiolabelling AmBisome with Tc-99m (Das, 2005).

\section{Other Agents}

\section{${ }^{99} \mathrm{~m}$ Tc-ubiquicidin}

Ubiquicidin (UBI) 29-41 is a cationic, synthetic antimicrobial peptide fragment that binds preferentially with the anionic microbial cell membrane at the site of infection. It is able to differentiate between bacterial infection and inflammation induced by lipopolysaccharides of bacterial origin. This was evaluated in animal models by Welling et al (2001) and in a recent phase I clinical trial on eighteen patients by Akhtar et al (2005). In suspected bone, soft-tissue and prosthesis infections the overall sensitivity, specificity, and accuracy were $100 \%, 80 \%$, and $94.4 \%$, respectively. 99mTc-UBI 29-41 showed promise in localizing foci of infection, with optimal visualization as early as $30 \mathrm{~min}$. 


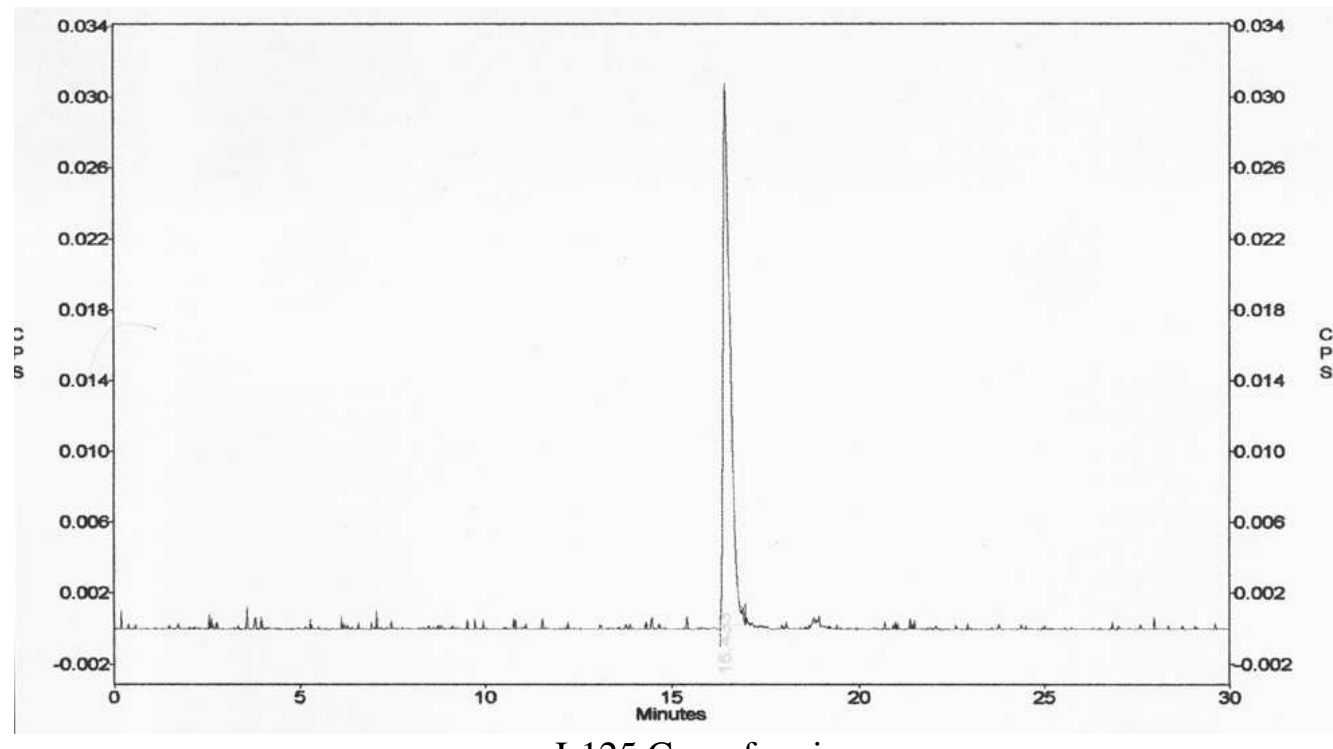

I-125 Caspofungin

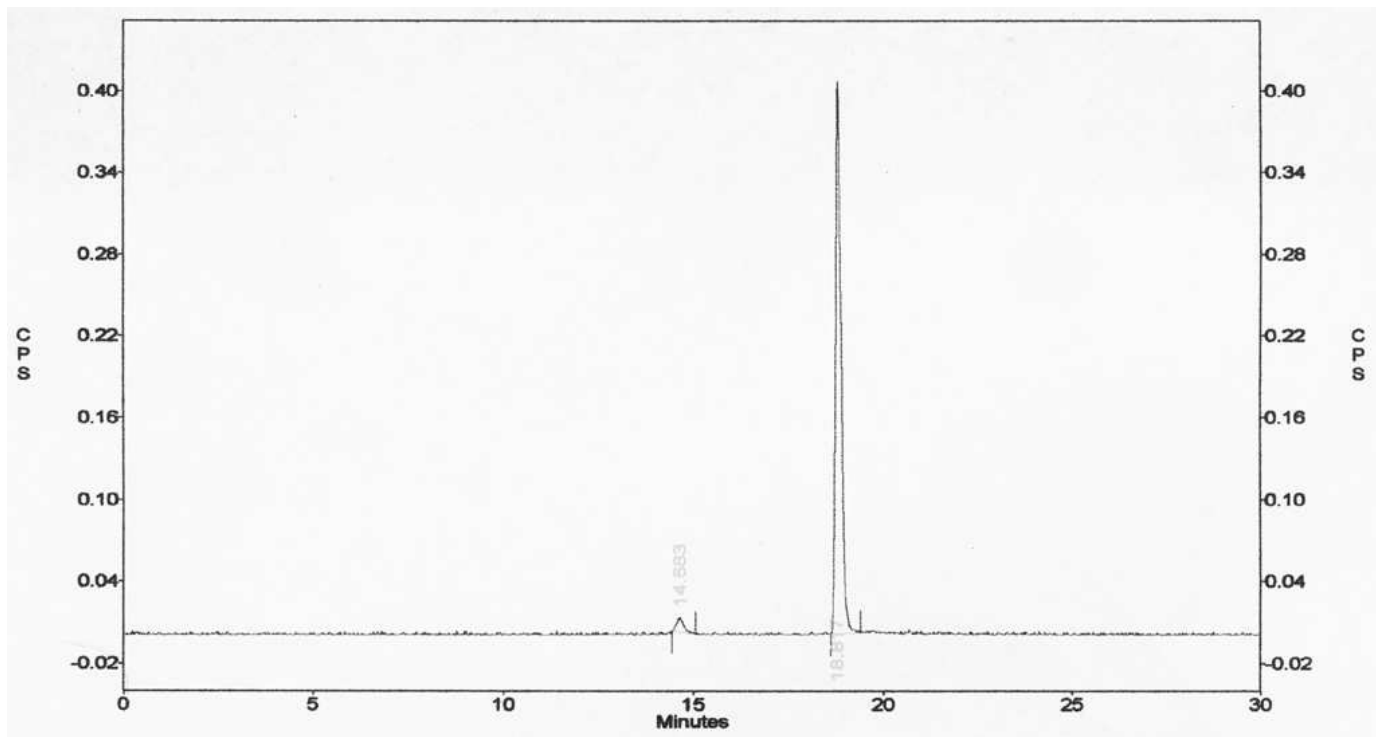

Tc-99m Voriconazole

Figure 2 - HPLC traces of Caspofungin and voriconazole following labeling with 1-125 and Tc-99m respectively

\section{$\left[{ }^{125} I\right] \quad$ FIAU 1-(2'-deoxy-2'-fluoro- $\beta$-D- arabinofuranosyl)-5-[ $\left[{ }^{125} \mathrm{I}\right]$ iodouracil}

A novel approach to bacterial specific imaging targeting bacterial thymidine kinases has recently been described by Bettegowda et al, (2005). Nucleoside analogues such as ganciclovir, penciclovir and zidovudine are used extensively in the treatment of viral infections where they act via inhibition of thymidine kinase involved in nucleic acid replication. The nucleoside 1-(2'-deoxy-2'- fluoro- $\beta$-D-arabinofuranosyl)-5- iodouracil (FIAU) was found to act as a substrate for $E$. coli thymidine kinase and after successful labelling with ${ }^{125}$ I was able to image $E$. coli abscesses in mice. $\left[{ }^{125} \mathrm{I}\right]$ FIAU was also able to image experimental infections with $E$. faecalis, $S$. aureus, $S$. epidermidis, and $S$. pneumoniae. As homologous thymidine kinases exist in all pathogenic bacteria sequenced to date, radiolabelled species specific nuceloside 
analougues may be a very useful means of imaging bacterial infections.

\section{${ }^{18}$ F-Deoxyglucose (FDG)}

For the last $15 \mathrm{yrs}{ }^{99 \mathrm{~m}} \mathrm{Tc}$ has been radiolabel applied to each new agent. Fluorine-18 fluorodeoxyglucose (FDG) is a positron emitter preferentially taken up by cells, which predominantly metabolise glucose as a source of energy, e.g. cancer cells, inflammatory cells and bacteria. Although FDG is not an infection specific agent, the possibility of applying labels other than ${ }^{99 \mathrm{~m}} \mathrm{Tc}$ which themselves apply some selectivity for bacteria in addition to the selectivity of the agent labelled may lead to a new generation of radiopaharmaceuticals.

\section{CONCLUSIONS}

Radiolabelled antimicrobials represent a novel approach to the diagnosis of deep seated infection. Controversies over the sensitivity and specificity of many of the preparations under evaluation remain, and will need to be addressed in larger clinical trials. ${ }^{99 \mathrm{~m}} \mathrm{Tc}$-ciprofloxacin (Infecton) has been subjected to such a trial, demonstrating good sensitivity and specificity in a wide range of bacterial infections and it may be especially useful in bone and joint infections. The availability of commercial preparations, subject to rigorous quality control, will be an important component in the development of novel imaging agents for use in clinical practice.

\section{RESUMO}

A medicina nuclear é uma técnica poderosa de diagnóstico capaz de detectar focos inflamatórios em doenças humanas. Uma ampla gama de agentes tem sido avaliada em sua capacidade de distinguir lesões, devidas a infecções microbianas daquelas causadas por inflamações estéreis. Avanços continuam sendo realizados no uso de antibióticos radiomarcados que, da mesma forma que têm sido usados no diagnóstico altamente específico de infecções, podem ser úteis na monitoração do tratamento e do curso da doença. Neste estudo, nós apresentamos uma atualização sobre estudos in vitro e clínicos, com alguns novos radiofármacos e outros já consagrados.

\section{REFERENCES}

Akhtar MS, Qaisar A, Irfanullah J, Iqbal J, Khan B, Jehangir M, Nadeem MA, Khan MA, Afzal MS, UlHaq I, Imran MB (2005). Antimicrobial peptide 99mTc-ubiquicidin 29-41 as human infectionimaging agent: clinical trial. J Nucl Med., 46, 567-73.

Artiko V, Davidovic B, Nikolic N, Petrovic M, Vlajkovic M, Pesko P, Knezevic S, Dukic V, Stefanovic B, Tulic C, Popovic N, Milosavljevic T, Obradovic V (2005) Detection of gastrointestinal and abdominal infections by $99 \mathrm{mTc}$-ciprofloxacin. Hepatogastroenterology., 52, 491-5.

Ball P Safety of the new fluoroquinolones compared with ciprofloxacin (2000). J Chemother., 12, Suppl $1: 8-11$.

Bererhi H, Hussein S, Wali Y (2003). Comparison of Tc-99m Ciprofloxacin (Infecton) and Tc- 99m Methylene diphosphonate (MDP) Three-phase Bone Scintigraphy in the Diagnosis of Osteomyelitis in Patients with Sickle Cell Disease. World J Nucl Med., 2, 110-115.

Bettegowda C, Foss CA, Cheong I, Wang Y, Diaz L, Agrawal N, Fox J, Dick J, Dang LH, Zhou S, Kinzler KW, Vogelstein B, Pomper MG (2005). Imaging bacterial infections with radiolabeled 1-(2'-deoxy-2'fluoro-beta-D-arabinofuranosyl)-5-iodouracil. Proc Natl Acad Sci U S A., 102, 1145-50.

Britton KE, Wareham DW, Das SS, Solanki KK, Amaral H, Bhatnagar A, Katamihardja AH, Malamitsi J, Moustafa HM, Soroa VE, Sundram FX, Padhy AK (2002). Imaging bacterial infection with (99m)Tc-ciprofloxacin (Infecton). J Clin Pathol., 55, 817-23.

Causse JE, Pasqualini R, Cypriani B, Weil R, van der Valk R, Bally P, Dupuy A, Couret I, Benbarek M, Descomps B (1990). Labeling of ethambutol with 99mTc using a new procedure. Pharmacokinetic study in the mouse and rat. Int J Rad Appl Instrum., 41:493-6.

Das SS, Hall AV, Wareham DW, Britton KE (2002). Infection imaging with radiopharmaceuticals in the $21^{\text {st }}$ century. Braz Arch Biol Tech, 45, 25-37.

Das SS, Britton KE (2003). Bacterial Specific Imaging. World J Nucl Med, 2,173-179.

Das SS (2005). Personal communication

De Kleijn EA, Oyen WJ, Corstens FH, van der Meer JE (1997). Utility of indium-111 polyclonal immunoglobulin $\mathrm{G}$ scintigraphy in fever of unknown origin (FUO). J Nucl Med, 38, 484-489. 
De Winter F, Gemmel F, Van Laere K, De Winter O, Poffijn B, Dierckx RA, Van de Wiele C (2004). 99mTc-ciprofloxacin planar and tomographic imaging for the diagnosis of infection in the postoperative spine: experience in 48 patients. Eur $J$ Nucl Med Mol Imaging., 31, 233-9.

Gemmel F, De Winter F, Van Laere K, Vogelaers D, Uyttendaele D, Dierckx RA (2004). 99mTc ciprofloxacin imaging for the diagnosis of infection in the postoperative spine. Nucl Med Commun., 25, 277-83.

Gnanasegaran G, Croasdale J, Buscomebe JR (2004). Nuclear medicine in imaging infection and inflammation: Part-I, radiopharmaceuticals. World J Nucl Med., 3, 155-165.

Gomes Barreto V, Iglesias F, Roca M, Tubau F, Martin-Comin J (2000). Labelling of ceftizoxime with 99mTc. Rev Esp Med Nucl., 19, 479-83

Hall AV, Solanki KK, Bomanjii JJ (1996) ${ }^{99 \mathrm{~m}} \mathrm{Tc}-$ Infecton. In-vitro binding to bacteria and clinical efficacy in imaging sites of infection. Abstracts of the $36^{\text {th }}$ Interscience Conference on Antimicrobial Agents and Chemotherapy, New Orleans, USA, 15-18.

Hall AV, Solanki KK, Vinjamuri S, Britton KE, Das SS (1998). Evaluation of the efficacy of 99mTc-Infecton, a novel agent for detecting sites of infection. J Clin Pathol., 51, 215-9.

Kleisner I, Komarek P, Komarkova I, Konopkova M. A new technique of $99 \mathrm{mTc}$-ciprofloxacin kit preparation (2002). Nuklearmedizin., 41, 224-9.

Larikka MJ, Ahonen AK, Niemela O, Junila JA, Hamalainen MM, Britton K, Syrjala HP (2002). Comparison of 99mTc ciprofloxacin, 99mTc white blood cell and three-phase bone imaging in the diagnosis of hip prosthesis infections: improved diagnostic accuracy with extended imaging time. Nucl Med Commun., 23, 655-61.

Lupetti A, Welling MM, Mazzi U, Nibbering PH, Pauwels EK (2002) Technetium-99m labelled fluconazole and antimicrobial peptides for imaging of Candida albicans and Aspergillus fumigatus infections. Eur J Nucl Med Mol Imaging., 29, 674-9.
Malamitsi J, Giamarellou H, Kanellakopoulou K, Dounis E, Grecka V, Christakopoulos J, Koratzanis G, Antoniadou A, Panoutsopoulos G, Batsakis C, Obradovic V, Artiko V, Petrovic N, Davidovic, Nikolic N, Vecetic C, Sobic-Saranovic D, TodorovicTirnanic M, Vlajkovic M (2003). Preliminary results of imaging orthopaedic infection with ${ }^{99 \mathrm{~m}} \mathrm{Tc}$ ciprofloxacin using a newly developed simple labelling kit. World J Nucl Med., 2, 269-274.

Proukakis C (2003). Infecton: a 99mTc-ciprofloxacin radiopharmaceutical for the detection of bone infection. Clin Microbiol Infect, 9, 101-9.

Peremans K, De Winter F, Janssens L, Dumont F, Van Bree H, Dierckx R (2002). An infected hip prosthesis in a dog diagnosed with a ${ }^{99 m}$ Tc-ciprofloxacin (infecton) scan. Vet Radiol Ultrasound., 43, 178-182.

Siaens RH, Rennen HJ, Boerman OC, Dierckx R, Slegers G (2004). Synthesis and comparison of 99mTc-enrofloxacin and 99mTc-ciprofloxacin $J$ Nucl Med., 45, 2088-94.

Singh AK, Verma J, Bhatnagar A, Ali A (2003). Tc99m labelled sparfloxacin: A specific infection imaging agent World J Nucl Med 1, 103-109

Singh AK, Verma J, Bhatnagar A, Sen S, Bose M (2003 a). Tc-99m Isoniazid: A specific agent for Diagnosis of tuberculosis. World J Nucl Med., 2, 292-305.

Tossing G (2004). 99mTc-ciprofloxacin DRAXIMAGE. IDrugs., 7, 374-9.

Vinjamuri S, Hall AV, Solanki KK, Bomanji J, Siraj Q, O'Shaughnessy E, Das SS, Britton KE (1996). Comparison of $99 \mathrm{mTc}$ infecton imaging with radiolabelled white-cell imaging in the evaluation of bacterial infection. Lancet, 347, 233-5.

Verma J, Singh AK, Bhatnagar A, Sen S, Bose M (2005) Radio-lebeling of ethambutol with technetium-99m and its evaluation for detection of tuberculosis. World J Nucl Med., 4, 35-46.

Wareham D, Das S, Britton K (2000). Imaging Infection. In: Wilcox M, editor. Fast Facts-Infection Highlights 1999-2000. Oxford: Health Press; 81-87.

Welling MM, Paulusma-Annema A, Balter HS, Pauwels EK, Nibbering PH (2000). Technetium-99m labelled antimicrobial peptides discriminate between bacterial infections and sterile inflammations. Eur $J$ Nucl Med., 27, 292-301.

Welling MM, Lupetti A, Balter HS, Lanzzeri S, Souto B, Rey AM, Savio EO, Paulusma-Annema A, Pauwels EK, Nibbering PH (2001). 99mTc-labeled antimicrobial peptides for detection of bacterial and Candida albicans infections. J Nucl Med., 42, 788-94. 